\title{
Correction to: Effect of social condition on behavioral development during early adult phase in Drosophila prolongata
}

\author{
Takashi Matsuo $^{1}$
}

Published online: 8 January 2019

(c) The Author(s) 2019

\section{Correction to: J Ethol (2018) 36:15-22 https://doi.org/10.1007/s10164-017-0524-x}

The article Effect of social condition on behavioral development during early adult phase in Drosophila prolongata, written by Takashi Matsuo was originally published electronically on the publisher's internet portal (currently SpringerLink) on 4 September, 2017 without open access. With the author(s)' decision to opt for Open Choice the copyright of the article changed on 18 December, 2018 to (C) The Author(s) 2018 and the article is forthwith distributed under the terms of the Creative Commons Attribution 4.0 International License (http://creativecommons.org/licen ses/by/4.0/), which permits use, duplication, adaptation, distribution and reproduction in any medium or format, as long as you give appropriate credit to the original author(s) and the source, provide a link to the Creative Commons license and indicate if changes were made.

The original article has been corrected.

Open Access This article is distributed under the terms of the Creative Commons Attribution 4.0 International License (http://creativecommons.org/licenses/by/4.0/), which permits unrestricted use, distribution, and reproduction in any medium, provided you give appropriate credit to the original author(s) and the source, provide a link to the Creative Commons license, and indicate if changes were made.
The original article can be found online at https://doi.org/10.1007/ s10164-017-0524-x.

Takashi Matsuo

matsuo@utlae.org

1

\footnotetext{
Department of Agricultural and Environmental Biology,

The University of Tokyo, Yayoi 1-1-1, Bunkyo-ku,

Tokyo 113-8657, Japan
} 